\title{
Potentials of Smart Phones in Educational Development of Nigerian Secondary School Students: A Review
}

\author{
Adediran, Elizabeth Morenikeji \\ Department of Curriculum Studies and educational Technology, Federal College of Education, PMB 2096, \\ Abeokuta, Ogun state, Nigeria
}

\begin{abstract}
The use of smartphone is gradually becoming a compelling learning tool used to enhance teaching and learning in distance education. Its usage ensures flexible course delivery, makes it possible for learners to access online learning platforms, access course resources and interact digitally. Students' use of smart phones and other convergent technological devices for study and social purposes has grown significantly in the past five years. This trend is part of a more general ICT revolution impacting on the way students interact both with each other and with their studies. Though, controversy exists on use of smart phones in schools, yet the device is full of potentials that could be tapped for educational purposes. This paper provides a review which critically examines the inherent potentials associated with mobile smart phone technology and how these potentials could be tapped for educational development of the Nigerian secondary school students. The paper also x-rays the need for proper guidelines be set for effective application of this technology within the Nigerian school system
\end{abstract}

DOI: $10.7176 / \mathrm{JEP} / 12-27-07$

Publication date:September $30^{\text {th }} 2021$

\section{INTRODUCTION}

The emergence of Information and Communication Technology (ICT) and internet facilities have drastically affected almost every facet of human life. Currently, it is greatly evident in the way of teaching and learning. Nowadays, smartphones have become a part of every person's life. Globally, "People around the world have adopted this new and exciting technology as one of the most important required facility in their everyday life" (Fawareh \& Jusoh, 2017; Masiu \& Chukwuere (2018). Globally, the explosion of smartphones and its related devices has greatly transformed teaching and learning in developed nations where developing nations are not the exception (Tagoe and Abakah, 2014). The proliferation of these facilities has changed the style of learning whereby students or learners no more solely depend on paper-based materials. The introduction of the internet led to the emergence of smartphones which enables learning to take place irrespective of the geographical location or period of time. Arguably, smartphones came to the scene to replace the works of the camera, video recorders, digital watches, etc. For instance, it is becoming so rare for an individual to purchase a digital camera for personal use except for commercial purposes, and the extent at which people yearn for digital watches has reduced as a result of the introduction of smartphones. In effect, it becomes redundant for one to purchase such gadgets which can be found in smartphones. Fawareh and Jusoh (2017) postulated that having a smartphone is like having a tiny computer in a pocket. It is blatant that, the potency of smartphone is not only meant for placing of calls and receiving of calls. Usually, there are amazing features such as for browsing, checking health status, sending and receiving emails, watching videos, listening to music, chatting, sharing photos, videos and other 3 documents, to mention but a few. No wonder there is an exponential use of social media as a result of the emergence of the smartphone. According to Masiu \& Chukwuere (2018), in the 21st century, smartphones have vastly increased due to its exciting features such as accessing emails, biometric, accessing social media platform and many more. According to Technopedia (2019) "A smartphone is a mobile phone with highly advanced features. A typical smartphone has a high-resolution touch screen display, WiFi connectivity, Web browsing capabilities, and the ability to accept sophisticated applications." Ebiye (2015) regards a smartphone as a smart device used for fast access to knowledge, geared towards students achieving their teaching and learning and academic research objectives. The dramatic growth of smartphone users has also increased the growth of social media users. Also, in a report from the International Telecommunication Union, it was indicated that about $60 \%$ of the world's population has access to mobile phones (Sarfoah, 2017). In the same report, it is interesting to note that there are more mobile phone users in the developing nations as compared to the advanced ones (Henry \& Quansah, 2013), which means, developing countries utilize smartphones the more.

Students' use of smart phones and other convergent technological devices for study and social purposes has grown significantly in the past five years. This trend is part of a more general ICT revolution impacting on the way students interact both with each other and with their studies. A smart phone is a device that can make and receive telephone calls over a radio link while moving around a wide geographical area (Sarfoah, 2017). Modern cell phones support a wide variety of other services such as, text messaging, multimedia messaging, email, internet access, bluetooth, business applications, games, photography and calendaring among other services. A smart phone is a device that makes calls but also adds on features that in the past were found on a personal 
computer such as, Microsoft documents, QWERTY keyboard, synchronizing personal and professional e-mail accounts (Attwell: 2015).

\section{Smart Phones and the Educational Setting.}

Smart phones are different from other cell phones because of their operating system such as, Android or Windows. With proper instructional design, smart phones can enhance educational opportunities because of their increased flexibility for learners. With a multitude of real-time streaming opportunities available through the phone, the trend is for students to use phones to multi-task, to plan and coordinate social and study-related activities, to facilitate group solidarity, and to gather information from a variety of sources. In spite of such affordances or perhaps because of them, smart phones can have much impact on study and academic performance. One trend which smart phone could impact on study is the tendency of students to multitask using smart phones. It is common for students to look at webpages and blogs, send and respond to texts and emails, check Facebook, or simply check their phones to see if there has been any activity. These actions occur at the same time as they are attending lectures, studying at home or in the library, or engaging in social activities. The affordances of a smart phone, or the properties of the technology that 'determine the possibilities for action' encourage their use for multitasking (Wood et al, 2012).

Another trend that smart phones can impact on study is for students to use their phones to arrange group activities. Some students are accustomed to technology infiltrating every area of their lives and use it to access entertainment, locate information, and stay in touch with their peers (Wood et al, 2012). Students prefer to facilitate arrangements using convergent technologies that allow texting and other non-synchronous communication channels as it suits their more dynamic and flexible lifestyle. They use the calendar and reminder and notes functions (applications) on their phones to manage study and other commitments. The phones also offer opportunities for micro-coordination (e.g. 'Coming... be there in 20 mins.'), synchronizing action and flexibility of schedules (e.g. using Viber and other free applications for group messaging), and for adjustments to plans 'on the go' (Wood et al, 2012). The use of smart phone also has an influence on study-related activities, like collaborative learning and virtual teams. Educators use its potential to exploit preferences of young students for experiential learning, and to enhance collaborative learning and build community within disciplines (Cochrane \& Bateman, 2010). The use of the smart phone as a convergent device for personal coordination is likely to increase with its growing availability and adaptability.

Smart phones allow perpetual access to interactive social media. Students can now have immediate and ready access to web 2000 sites through the apps on their phones. This trend can have negative impacts on study because it allows students to be distracted by social networking. Phones are used for socializing many times in a day - for texting, e-mailing, talking, using Facebook, and instant messaging. Moreover, these activities are frequently conducted while students are studying and attending classes (Jonnavithula \& Tretiakov, (2012). Indeed, Facebook and texting are preferred to calls for contact during class, as they allow for more discreet contact. This continual access to social networking sites is emerging as a noticeable feature of smart phones.

There are a number of impacts of smart phones on study but not all impacts on students are negative. In many courses, such as creative art and business subjects, mobile technology is being used to facilitate group interaction and reflective practice. The principal benefits noted by researchers in creative disciplines are greater student collaboration in project work, 'increased interaction from external commentators, and the development of student reflective journals' (Cochrane \& Bateman, 2010). The research into the pedagogical affordances of smart phones in tertiary education highlights the value of students being able to engage deeply with discussions about project "validity and outcomes. As the use of the technology increases these benefits are more likely to become apparent and be exploited to enhance students' engagements and learning.

According to Wood et al, (2012) students are susceptible to trends, fashions and styles, which make them more willing to adopt new technology such as, smart phones. As new technologies emerge, the study habits of students also evolve. Smart phones have changed the traditional college experience and to meet these challenges, learning institutions must embrace the new technology for learning. Cell phone use has been increasing in all economic and age sectors and has expanded the boundaries of education into an 'anytime, anywhere experience' (Cochrane \& Bateman, 2010) leading to students being labelled as one of the most important markets and the largest consumer group of mobile phone services (Domingo and Garganté (2016). Smart phones are presenting new means for students to access information thereby redefining the educational experience. Redefining this educational experience however presents new challenges for both educators and learners as they have to determine optimal mixes of technology and pedagogy.

Junior secondary education is the upper level of basic education and important segment of the 6-3-3-4 educational system. Junior secondary segment is designed to offer the learners relatively permanent literacy, numeracy, communication as well as manipulative skills. It is the actual implementation level of the tenets of universal basic education. The central tendency of this basic level is to train the citizens who can solve their personal and community problems without resorting to violence. By this, management of learners may imbibe 
necessary values, attitudes, skills and knowledge necessary for two reasons. First being to $\mathrm{ft}$ in and function effectively as a member of the community, also as the foundation for further education.

Due to the ubiquitous revolution of borderless education, Mobile learning is now considered as a knowledge-centric catalyst in supporting personalized and collaborative learning in secondary education. It is imperative to identify the role and the views of teachers and students who are the stakeholders in secondary education as they are responsible in utilizing the mobile devices. Deployment of state-of-the-art mobile technologies alone would not suffice sans taking considerations of the end-users or stakeholders' views, needs and wants. Nonetheless, challenges are inevitable in the mobile learning management pertaining to classroom issues, security measurement and monitoring concerns.

Smart phone as a mobile learning device for classroom is a "new opportunities for increasing engagement, motivation and learning". As a result, it fosters critical thinking skills, which are fundamental in the foundation of knowledge-centric and tech-savvy community in schools. As a general knowledge that most of the concerns and challenges identified from the existing literatures have more bearing on the end users' views and expectations which will contribute to the development of mobile applications that cater to the needs and wants of the education community. Emphasis should be made on the importance of studying the strategic planning and implementation of smart phones in order for it to be successfully executed and carried out.

There are enormous concerns about smart phones use according to gender and location divide today. There is already evidence that gender inequalities are being replicated in schools with girls using computers and the internet's less than boys (Domingo and Garganté (2016), but female students are found to be gratified through the use of smart phones; hence, ban on smart phones become bias against female. According to Olson et al (2011) the bias spread of the internet facilities also hinder students from rural communities who may be cut-off from mobile learning.

The use of smartphones has come to stay globally. It is gradually increasing and diversified across different sectors of education, both in developed and developing countries and commonly observed among the youths within and outside the school system. Its use is so widespread and uncontrolled among the youths in Nigeria.

In some parts of the world, use of smart phones and other mobile learning devices have been banned by the school board and enforced by both teachers and school administrators. This has been supported by parents. While the school board tends to justify themselves that the devices support anti-social activities like cultism, exams malpractice and prostitution (which may not be rampant, if not possible among junior secondary learners); the teachers feel that they may constitute sources of distraction and parents tend to belief these trusted groups and seek to hide under these to keep away from the high cost of these

devices. There are regulations in Secondary Schools prohibiting the use of mobile devices in school, among the students. This goes with punitive measures varying from among the schools. In spite of the ban, students still acquire and use smart-phones after school; even more than the teachers do, and are even spotted in the hostels within the school vicinities.

However, there tend to be continuously and geometrically high rate of these anti-social events, poor psychomotor and affective skills. The inseparable quest for knowledge and information from the town (society) among the gown (students) still gives a high craving for smart phones among the students which is difficult to suppress. This had led to circumvention of these rules especially as owners tend to use them to heighten the vices and also enhance learning. With all these efforts at exterminating the sources of vices in schools and among students, the rate of these vices is still on geometric increase. These devices are still being acquired by and spotted with students within and outside the schools for their social purposes. The poor performance among junior secondary has been attributed to poor instructional strategies, like poor use of black boards, lack of projectors and other factors. Each stake holder blaming the other and remaining confused on what might be the cause.

It is obvious that not many schools in Nigeria have the luxury of computers and worse still such schools may still not be able to have computers in the nearest future. However, it is observable, that the mobile phone is becoming ubiquitous among our secondary school age children in Nigeria. These phones may be used to serve the 'bring your own device' method of providing easy access to ICT in class. It is also true that not all teenagers have mobile phones. Also, while only a few may have smartphones, majority may have older 'dumb' phones especially, pupils from lower-income backgrounds. So, what could be done in class generally may be limited, but it is better than nothing.

\section{Challenges associated with smart phone use by students.}

Generally, mobile phones can be used to provide an exciting. world of creativity in classroom. (Wood et al, 2012) asserted that teachers are finding interesting and creative ways to include mobile phones classroom instruction in an effort to bridge the divide between the technologies children use at home and what they use in school: The mobile phone is a portable device that allows access to course material for both teachers and students anywhere and anytime. Teachers and students can use cell phones to communicate and interact. From a student perspective, 
cell phones allow them to Multitask (Domingo and Garganté (2016) by accessing course material, conducting research via the Internet, and communicating with peers and teachers in what could otherwise be periods of dead time '(Güliz Uğur and Koç (2015). In the same vein, instead of the negative use of texting, it could be used for a number of classroom applications. Texting can be used for interaction and communication between teachers, students and content (Wood et al, (2012); Domingo and Garganté (2016). Texting can also be employed for student assessment, cell phones can be utilized for assessing student performance of students in his study who took tests by cell phone performed Comparably with students who did so by conventional methods. The digital camera has also been found useful in classroom applications. Güliz Uğur and Koç (2015), found that 83\% of teens reported having taken a picture with their cell phones. Areas where the cameras cab be used in the classroom include collection of data, scientific visualization, communication in science, and visual communication in language arts and inquiry in social. studies (Güliz Uğur and Koç (2015). Cell phones also have the ability to allow teachers and students to connect to the internet. The. internet can support: communication, collaboration, the collection and analysis of information and individual and cooperative Problem-Solving (Ally \& Prieto-Blázquez, 2014). Learners use smartphones to access up-to-date and relevant educational resources and they also enable students to communicate with experts in the field of their studies so that they gain more insight and enrich their learning (Ally \& Prieto-Blázquez, 2014). Domingo and Garganté (2016) also reveal that providing access to information and increasing engagement while learning are the two main impacts of mobile technology in the classroom. Martin and Ertzberger (2013) point out that "a mobile-based learning environment, by virtue of its portability, will provide scaffolding when and where students need it whether in the classroom or investigating in the field". This was also pointed out by (Ally \& Prieto-Blázquez, 2014). Obviously, mobile learning provides a range of opportunities and a certain level of flexibility to students. Much as continuous connection to resources is good for the learner, Güliz Uğur and Koç (2015) warns that this use of smartphones during class creates a negative impression towards the lectures or instructors. Rather than enriching the learner's education, continuous use of smartphone during class might ends up destroying the student's reputation towards the lecturer. Some lecturers consider phone use disrespectful especially when it occurs during lectures (Güliz Uğur \& Koç, 2015). From their research on misuse of mobile technology, they found that "about $40 \%$ of the students indicated that they used their phones during class" (Güliz Uğur \& Koç, 2015), and this activity interrupted about 85\% of their colleagues. Their article emphasises the fact that smartphone use causes loss of attention to students during studies. Students interacting with their phones tend to miss out on what is being taught. The use of smart phones during class to receive calls, text or notification does not only affect the recipient or user but also those around him or her. Smart phones are expected to play a supportive role in the learning process. Providing variety of resources in different formats that can be conveniently accessed by the students. Some scholars on the other hand report that student use smart phones for academically unrelated endevors e.g. to play games and other things that are unrelated to their studies. Ifeanyi \& Chukwuere, (2018) claim that "a third of college students in the U.S. play video games on their mobile phones during class" . This undermines the supportive role of smart phones in the learning process. Keengwe and Bhargava (2013) stress the value of texting or instant messaging which is one of the celebrated functionalities of smart phones. They argued that this is one effective way of sharing ideas and gaining insight for the learners. "Knowledge develops through interactions among human beings and these social interactions lead to knowledge transformation" (Ally \& Prieto-Blázquez,. (2014). (Kuznekoff and Titsworth (2013) on ther other hand believe that texting during classes is an interference to learning. While studying the impact of phone usage on students during class, they found out that " $64 \%$ of teens who own cell phones have texted during class, even in schools where cell phones are technically banned" (Kuznekoff \& Titsworth, 2013). According to Kuznekoff and Titsworth (2013), these "texts potentially come at the expense of learning, as texting during class reduces students' ability to self-regulate and give sustained attention to classroom tasks". Besides the challenges posed to learning, "classroom texting/posting produces negative consequences for students and instructors" (Misagal, (2016).

\section{Conclusion}

Smart phones have advantages and disadvantages. We cannot because of the disadvantages throw away the potentials. In fact, whether schools allow its use or not, these devices are being used by students anyway, especially when outside the school environment. So, the sooner schools allow its use, the better. The only onus on educators is to guide the pupils towards making appropriate and profitable use of these devices. It is also important to stress that the use may help to bridge a little the information gap already created for developing worlds through ICT.

\section{Way forward}

In summary, it is important to understand that smartphones provide the means for students to access and 
disseminate information rapidly in a very timely and convenient way. This is why they can greatly enhance the learning process but if their use is not carefully regulated, they can compromise learning. "Students are spending time texting, they are not paying attention in class" (Guliz Ugur \& Koc, 2015). It is therefore crucial for students to take required steps and ensure that their use of smart phones supplements their learning experience. Interviews with Nigerian on their perceptions of smart phones in the classroom revealed that, not only were the vast majority of them already using their phones at school, but also their views as a group were largely discrepant. Most students ( 70 per cent) could identify benefits associated with mobile smart phones in the classroom, such as increased engagement, motivation for learning, creativity and productivity. However, almost a third of the cohort reported concerns regarding disruption and misuse of smart phones - particularly under exam conditions - and harmful activities such as cyber bullying and sexting. As for teacher attitudes towards mobile phone use, the research has been mixed, with some researchers demonstrating positive support for mobile phones in the classroom and others suggesting they should be left at home).

Anecdotal reports also reveal successful phone integration in the classroom. Today's smartphones are microcomputers with the capacity to provide many of the advantages that technology can afford in terms of accessing a broad, deep and meaningful education. A plethora of phone apps have been encouraged by schools, particularly those that support wellbeing by building on relaxation skills and offering help seeking resources. Smartphones have endless possibilities as educational tools, which is why some schools tolerate them. Others ban them, or AT LEAST, attempt to do so.

Then there is the small matter of social skills. While smartphones do offer opportunities to connect with others and facilitate a sense of belonging and community, there is a time and place. I recently overheard a small child ask her mother why Daddy had an angry face. A subtle glance over at the next table revealed that "Daddy" was on his smartphone. There was no angry face, but rather a serious, engrossed-reading-face summoned from the undecorated monotropic concentration needed to focus on reading small font in a noisy cafe. These scenarios make me question whether smartphone use is helping or hindering the social development of children (not to mention the social abilities of the smartphone users themselves).

Ultimately, good sense must prevail as we harness the strengths of the technology and practice everything in moderation. Smartphone use will remain an ongoing issue for parents and schools, particularly in terms of content and what is considered suitable, and also how it should be managed. There will always be misuse as we have seen recently with students bring mobile phones into examination settings. Schools should be at the forefront of ensuring their mobile phone use policies and practice match current telecommunication technologies.

With problematic phone use now considered a risk behaviour alongside alcohol, tobacco and marijuana use, schools should ensure they are addressing the psychological, social and health issues associated with technology (e.g. a lack of sleep from late night phone use, cyber bullying, sexting). By building some of the health-related implications of technology into the curriculum, we may be able to mitigate potential harm and promote the safe, controlled and productive use of mobile phones.

Both schools and parents have a role to play in boundary setting, providing guidance with appropriate and inappropriate phone use, and teaching self-regulation and self-control skills. Parents can and should serve as appropriate role models for telephone use. That's not to say that parents should only use their smartphones in private but they should try to employ the same phone etiquette they are trying to teach their children.

Ultimately, school is a microcosm of wider society. Just as using a smartphone may be unacceptable during a job interview, neither is it in the middle of a classroom. Knowing that certain behaviour is acceptable in some places, but not in others is at the crux of how young people can better use mobile phones responsibly and fruitfully at school and the society at large.

\section{References}

Ally, M., \& Prieto-Blázquez, J. (2014). What is the future of mobile learning in education? International Journal of Educational Technology in Higher Education, 11(1), 142-151. https://doi.org/10.7238/rusc.v11i1.2033

Cochrane, T., \& Bateman, R. (2010). Smartphones give you wings: Pedagogical affordances of mobile Web 2.0. Australasian Journal of Educational Technology, 26(1).

Czerniewicz, L., \& Brown, C. (2010). Born into the Digital Age in the south of Africa: the reconfiguration of the "digital citizen." Proceedings of the 7th International Conference on Networked Learning, 859-865.

Domingo, M. G., \& Garganté, A. B. (2016). Exploring the use of educational technology in primary education: Teachers' perception of mobile technology learning impacts and applications' use in the classroom. Computers in Human Behavior, 56, 21-28. https://doi.org/10.1016/j.chb.2015.11.023

Elfeky, A. I. M., \& Yakoub, M. T. S. (2016). The Effect of Mobile Learning on Students' Achievement and Conversational Skills. International Journal of Higher Education, 5(3), $20-31$. https://doi.org/10.5430/ijhe.v5n3p20

Fawareh H. M. A., Jusoh, S. (2017). The Use and Effects of Smartphones in Higher Education. IJIM (11), 6. Güliz Uğur, N., \& Koç, T. (2015). Mobile Phones As Distracting Tools in the Classroom: College Students 
Perspective. Journal of Operations Research Statistics, 3(32), 57-64.

Ifeanyi, I. P., \& Chukwuere, J. E. (2018). The impact of using smartphones on the academic performance of undergraduate students. Knowledge Management \& E-Learning, 10(3), 290-308

Jonnavithula, L., \& Tretiakov, A. (2012). A model for the effects of online social networks on learning. Future challenges, sustainable futures. Proceedings ascilite Wellington, 1(30), 435-437.

Keengwe, J., \& Bhargava, M. (2013). Mobile learning and integration of mobile technologies in education. Education and Information Technologies, 1-10. https://doi.org/10.1007/s10639-013-9250-3

Kuznekoff, J., \& Titsworth, S. (2013). The Impact of Mobile Phone Usage on Student Learning. Communication Education, 62(3), 233-252. https://doi.org/10.1080/03634523.2013.767917

Martin, F., \& Ertzberger, J. (2013). Here and now mobile learning: An experimental study on the use of mobile technology. Computers and Education, 68, 76-85. https://doi.org/10.1016/j.compedu.20 13.04.021

Masiu, M.T \& Chukwuere, J. E (2018). The Effect of Smartphones on Students' Academic Life: A Perceptive from a South African University. International Conference on Business and Management Dynamics ICBM2018.

Misagal, L. V. (2016). Smart phones usage among college students. IMPACT: International Journal of Research in Engineering \& Technology, 4(3), 63-70.

Sarfoah, E. (2017). Smartphone use for learning: A study on University of Ghana students. (Unpublished MPhil Thesis). Department of Communication Studies, University of Ghana

Tagoe, M., \& Abakah, E. (2014). Determining distance education students' readiness for mobile learning at University of Ghana using the Theory of Planned Behavior. International Journal of Education and Development using Information and Communication Technology, 10(1), 91.

Wood, E., Zivcakova, L., Gentile, P., Archer, K., De Pasquale, D., \& Nosko, A. (2012). Examining the impact of off-task multi-tasking with technology on real-time classroom learning. Computers \& Education, 58(1), 365-374. 